\title{
The Situation of Young Mothers in Changing Social and Economic Circumstances in Some Eastern European Countries
}

Authors' contribution:

A) conception and design of the study

B) acquisition of data

C) analysis and interpretation of data

D) manuscript preparation

E) obtaining funding

\section{Barbara Abonyi}

University of Physical Education in Budapest, Hungary
In 2011, we conducted a comparative research study in the V4 countries and in Romania among young mothers who had given birth in the past up to three years prior. In consolidated historical periods, sweeping changes seldom occur over five years. However, noticing how the worldwide financial and economic crisis of 20072011 had a varying impact on the countries of the Eastern European region, we became interested in discovering how the social and economic changes influenced the working status of some young mothers and their health-related customs, including their physical activity, back pain, and smoking habits. In 2016, we had the chance to repeat the essence of the previous research in Hungary, Romania, and the Slovak Republic. The objective of this paper is to present the major results of the second study and compare them with the findings of our previous investigation. The methods used in the present research were borrowed from the previous one; the findings of the two investigations can thus be fairly compared. The results are presented according to the following sub-topics: the young mothers' working status, use of childcare frequency of physical activity, presence of back pain, and smoking habits. In conclusion, it is stated that the relevant changes in the young mothers' social and economic environment serve as a fair explanation for their changing situations in the studied countries.

young mothers, working status, physical activity, back pain, smoking habits

\section{Introduction}

In late 2011 and early 2012, we conducted a comparative research study in the V4 countries and in Romania focusing on young mothers' physical activity and back pain. The results of this investigation were published in the journal Physical Culture and Sport. Studies and Research (Abonyi 2013). In early 2010, a major justification for carrying out a comparative study of some post-communist countries was found in their similar position in the human development ranking prepared by the United Nations Development Program, in addition to their similar histories (Human Development Report, UNDP 2010). We noticed that in the following years, the development of these countries went in different directions. By the middle of the decade, one of 
them improved its place in the rank, (the Czech Republic was ranked $28^{\text {th }}$ versus $33^{\text {rd }}$ in 2011), while others were ranked lower: in the 2016 report, Hungary was seven places lower than in 2010 (from $36^{\text {th }}$ place to the $43^{\text {rd }}$ ), and the Slovak Republic lost four positions (from $36^{\text {th }}$ to $40^{\text {th }}$ ) Romania kept its ranking at number 50, and Poland remained more or less in the same place (from $37^{\text {th }}$ to $36^{\text {th }}$ place). (Human Development Report Ranking, 2015). At the same time, we also remarked that in the individual countries involved in our earlier research, different measures were taken with regards to the population's health protection and sporting activity and the social situations of young mothers.

Moreover, the global financial and economic crisis of 2007-2011 had different consequences that gradually spread at a dissimilar rate in the different sections of the given societies. From 2011 onwards in the countries concerned, the real value of household incomes gradually decreased. The decline was especially strong in Romania and moderate in Hungary and in the Slovak Republic. In those years, the stabilizing effect of social expenses on the households decreased because of the increasing rate of unemployment, among other things. Part-time work became rare in Hungary (5.1\%) and in the Slovak Republic (5.5\%) (Eurostat 2015). At the same time, the employment rate of women increased between 2011 and 2016 in the countries concerned: from $72.5 \%$ to $76.9 \%$ in the Slovak Republic, from $71.5 \%$ to $75 \%$ in Romania, and from $66.4 \%$ to $78.6 \%$ in Hungary, representing the largest increase (Eurostat 2016). According to Földesi (2014), grassroots sports were the real losers of the crisis. Ríos et al. (2013) ranked these countries in the "globally lower motivation to exercise" group.

In consolidated historical periods, sweeping changes seldom occur over five years. However, noticing all the recent transformations, we became interested in discovering how the varying degrees of economic advancement and the relevant measures taken in these countries had an impact on the working position and health-related activities of young mothers. We wanted to know how the above-mentioned factors influenced their lives, including their physical activity and back pain levels. Therefore, in the mid-2010s we decided to carry out a research project similar to the one we had completed earlier that decade.

In 2016, we had the chance to repeat the essence of the previous study in Hungary, Romania, and the Slovak Republic. The objective of this paper is to present some major results of the second study and compare them with the findings of our previous investigation.

This time, we added another important issue to the research questions: the smoking habits of young mothers. Although we acquired some information about this in our former study, we did not specifically deal with this theme at that time. Since then, the European Commission has called for a smoke-free Europe by 2012, and radical anti-smoking measures have been adopted all over the continent, including in Eastern Europe (European Commission 2017).

Since the habit of smoking is particular importance with young mothers, we created research questions concerning this topic as well.

\section{Methods}

\section{Population and characteristics of the sample}

We conducted the new study in late 2016 and early 2017, in November, December, January, and February - the same months as in the previous study five years earlier. The scenes of the investigation were also the same in 2016: the outskirts of Budapest, Hungary; the outskirts of Târgu Mureș and Sfântu Gheorghe in Romania; and the outskirts of Bratislava, Komarno, and Košice in the Slovak Republic.

With the help of structured sampling, 110 young mothers ( $N=110$ ) were selected (in 2011, $N=128$ ). The participants of the two studies were different, but the criteria for selecting them were the same: (1) the young mothers had to be less than three years after childbirth; and (2) they had to be well educated (having a university or at least secondary school degree). The national sub-samples have the major characteristics listed below.

The Hungarian young mothers $(\mathrm{n}=35)$ are 37.14 years old on the average and have an average of 2.34 children. In total, $97 \%$ of them hold a masters or bachelor's degree, and only $2.9 \%$ of them have secondary education. Compared to the 2011 sub-sample, these young mothers are on the average a little younger, have more children, and are better educated. 
The Romanian young mothers $(\mathrm{n}=44)$ are 31.78 years old on the average, and have an average of 1.25 children. All members of the sub-sample have a masters or bachelor's degree. This means that the sub-samples of 2011 and 2016 show more similarities with each other than differences; they differ from one another only in the level of education, which is higher in the second sub-sample.

The Slovakian young mothers $(\mathrm{n}=31)$ are 35.23 years old and have an average of 1.77 children. In total, $90.3 \%$ of them hold a masters or bachelor's degree, and $9.7 \%$ of them graduated from secondary school. Comparing these characteristics with those of the 2011 sub-sample, it can be seen that the Slovakian young mothers are considerably older, and have somewhat fewer children, and a higher level of education than in the previous investigation.

\section{Data collection}

The data were collected by the same questionnaire used in 2011, but this questionnaire was complemented by a few new questions focusing on the young mothers' smoking habits. Each young mother received and answered the questionnaire via the Internet in her mother tongue. The questionnaire dealt with the following major themes:

1. Current social status

2. Use of childcare

3. Current frequency of physical activity

4. Presence and frequency of back pain

5. Smoking habits

\section{Treatment of the data}

The data were processed with the help of SPSS.17. Then, descriptive statistics and crosstabs were used. The assessment of the significance of the margin of error $(\mathrm{p}<0.05)$ was regarded as a basis, as it is generally accepted in research related to the social sciences.

Considering the methods used, the results of the two investigations can be fairly compared.

\section{Relevant changes in young mothers' social and economic environments}

In Hungary, there was a change in the mothers' paid leave (until the child is three years old). Mothers can return to employment half a year earlier without losing family support (Gyermekgondozási segély, 2016). Daycare facilities tended to be overcrowded for children under the age of three (Blaskó et al., 2012). Therefore, in 2015 the government made a decision to expand their capacity. Flexible and differentiated possibilities for childcare provision were planned for children under the age of three. In this area, a decrease in inequality between regions, as well as an increase in the number of workplaces and in the employment of women, has been initiated (National Social Report, 2016).

The country's GDP has decreased by almost $\$ 10$ billion. In 2017 , it was estimated to $\$ 118.0$ billion (Global Finance Magazine, 2017a).

The Hungarian population became less physically active than it was half a decade ago. According to the Eurobarometer of 2014, more people are totally inactive (44\% versus $32 \%$ ), and fewer are physically active on a daily basis (15\% versus 26\%) (Gál, 2008; Special Eurobarometer 412, 2014).

As a result of stricter smoke-free regulations, the percentage of smokers decreased from $36 \%$ to $27.5 \%$ in Hungary (Eurostat 2016).

In Romania in 1990, family support was available for the first four children. In 2005, it was limited to the first three children. In 2012, however, these criteria were changed, and the limitation on the number of births was eliminated. Some measures were set back, while others were restructured or cancelled permanently. For instance, non-working parents were totally excluded from childcare allowance, including maternity grants for newborn babies (PERFAR, 2014).

At the same time, the GDP increased in Romania by almost $\$ 10$ billion dollars, from $\$ 186.4$ billion to \$197.00 billion (Global Finance Magazine, 2017b).

According to the Eurobarometer of 2014 , very few Romanians participated in daily physical activity 
(6\%); those who participated regularly made up $15 \%$ of the population, while $18 \%$ of them were rarely physically active and $60 \%$ of them never participated in physical activity (Special Eurobarometer, 2014).

As in Hungary, strict smoke-free regulations have been introduced in Romania in the past few years. Consequently, the percentage of Romanian smokers has decreased from 36\%, to 25.7\% (Eurostat, 2016).

In the Slovak Republic, the maternity allowance, which used to be $90 \%$ of the mother's last salary, was reduced to $55 \%$ of it in 2003. In 2011, it was increased to $60 \%$, and in 2012 to $65 \%$. (Valkova, 2012). The length of maternity leave was increased to 34 weeks in 2010.

The rise in the country's GDP was insignificant in this period. It was estimated to be $\$ 94.8$ billion in 2017 (Global Finance Magazine, 2017c).

The Slovakians are also rather physically inactive. Very few people did some physical activity daily (6\%), $28 \%$ of them did it with some regularity, $25 \%$ of them seldom, and $41 \%$ of them never participated in physical activity (Special Eurobarometer 412, 2014).

The percentage of smokers decreased from $36 \%$ to $29.6 \%$ (Eurostat, 2016). This country has some of Europe's most peculiar smoking laws. Smoking is prohibited only in workplaces, where non-smokers work. In restaurants, smoking areas can occupy $50 \%$ of the overall area.

\section{Results}

\section{Current working status of young mothers}

The changes in young mothers' working statuses were the most conspicuous in the Slovak Republic. The relevant data of 2016 are opposite to the data from 2011. According to our research findings, in 2016 the majority of young mothers stayed at home with their baby, while in 2011 three-quarters of them were employed.

In Hungary and Romania, the changes in this area were not as significant as in the Slovak Republic. However, comparing the current data with the results of the previous study, we can observe that in Hungary somewhat fewer mothers stay at home with the baby, less are employed full time, and more of them have become part-time workers, while in Romania more young mothers work full time (Table 1).

Table 1. The working status of young mothers in 2011 and 2016

\begin{tabular}{lll}
\hline & 2011 Working status & $\mathbf{2 0 1 6}$ Working status \\
$\mathrm{N}=128$ & $\mathrm{~N}=110$ \\
\hline Hungary & $(\mathrm{n}=36)$ & $(\mathrm{n}=35)$ \\
& $21.4 \%$ full time & $15.2 \%$ full time \\
& 17.9\% part time & $27.3 \%$ part time \\
& 60.7\% home & $57.6 \%$ home \\
\hline Romania & $(\mathrm{n}=46)$ & $(\mathrm{n}=44)$ \\
& $25.6 \%$ full time & $36.4 \%$ full time \\
& $18 \%$ part time & $13.6 \%$ part time \\
& $56.4 \%$ home & $50 \%$ home \\
\hline Slovak Republic & $(\mathrm{n}=46)$ & $(\mathrm{n}=31)$ \\
& $71.4 \%$ full time & $12.9 \%$ full time \\
& $23.8 \%$ part time & $3.2 \%$ part time \\
& $4.8 \%$ home & $83.9 \%$ home \\
\hline
\end{tabular}

Source: Own study.

\section{Young mothers' use of childcare}

Here, only the data concerning the young mothers who work full-time and part-time were taken into consideration. There were no considerable changes in Hungary and Romania concerning childcare while young mothers work. In Hungary, only the number of those families who use the service of baby-sitters increased a bit. In Romania, fewer young mothers call baby-sitters when they go to work; more of them now resort to daycare services. A sweeping change can again be observed in the Slovak Republic, where the number of working young mothers has decreased significantly. None of them resort to a creche as opposed to the previous 
study, when more than half of them did. They employ baby-sitters or solve the childcare problem within the family (Table 2).

Table 2. Childcare for young working mothers (2011 and 2016)

\begin{tabular}{lll}
\hline & 2011 Childcare & 2016 Childcare \\
& $\mathrm{N}=54$ & $\mathrm{~N}=42$ \\
\hline Hungary & $(\mathrm{n}=12)$ & $(\mathrm{n}=15)$ \\
& $0 \%$ babysitter & $6.7 \%$ babysitter \\
& $50 \%$ family & $46.6 \%$ family \\
& $50 \%$ creche & $46.7 \%$ creche \\
\hline Romania & $(\mathrm{n}=21)$ & $(\mathrm{n}=22)$ \\
& $28.6 \%$ babysitter & $18.2 \%$ babysitter \\
& $57.1 \%$ family & $59.1 \%$ family \\
& $14.3 \%$ creche & $22.7 \%$ creche \\
\hline Slovak Republic & $(\mathrm{n}=21)$ & $(\mathrm{n}=5)$ \\
& $0 \%$ babysitter & $20 \%$ babysitter \\
& $42.9 \%$ family & $80 \%$ family \\
& $57.1 \%$ creche & $0 \%$ creche \\
\hline
\end{tabular}

Source: Own study.

\section{Frequency of young mothers' physical activity}

In conformity with the former research, we made a distinction between young mothers according to the frequency of their physical activity. We created groups consisting of "physically active daily", "physically active 2-3 times a week", "physically active monthly", and "physically inactive" young mothers.

The results showed that significantly more young mothers are more physically active than they were five years ago $(\mathrm{p}=0.002)$. In Hungary five years ago, most young mothers were active only weekly; now, $45.7 \%$ of them do some physical activity a minimum of two or three times a week. Although the number of inactive Hungarian young mothers has increased a bit, it is still much less than in Romania and the Slovak Republic; the rate of young mothers who are more or less inactive is around $60 \%$ in both countries. Nevertheless, the similar findings cover totally different trends: in Romania has seen a considerable increase, while the Slovak Republic has had a radical decrease.

At the same time, the proportion of physically active young mothers increased significantly in the Slovak Republic, while in Romania only the rate of young mothers who are regularly physically active doubled; most (65.9\%) young mothers are inactive or do something physically active only monthly, which is insignificant from the point of efficiency (Table 3).

It is also worth mentioning, that in 2011, more than half of the young mothers did their physical activity in groups and the rest of them worked out individually, while in 2016 a changing tendency could be registered. Less than the half of them joined groups, and there were more young mothers exercising individually.

\section{Frequency of young mothers' back pain}

Parallel to the increase in physical activity in the Slovak Republic, young mothers' back pain has decreased by half as well. Positive changes can also be observed in Romania. Five years ago, only one-third of young mothers never suffered from back pain, while in 2016 half of them never suffered from back pain. A contradictory tendency was discovered in Hungary. On the one hand, the number of young mothers who never have any back pain has decreased by $50 \%$ in the last five years. On the other hand, twice as many young mothers complain from frequent back pain than before. The correlation between the current sporting activity and back pain is significant at the level of 0.042 (Table 4). 
Table 3. Frequency of young mothers' physical activity

\begin{tabular}{lll}
\hline & 2011 Physically active & 2016 Physically active \\
young mothers & young mothers \\
$\mathrm{N}=128$ & $\mathrm{~N}=110$ \\
\hline Hungary & $(\mathrm{n}=37)$ & $(\mathrm{n}=37)$ \\
& $27.8 \%$ regularly & $45.7 \%$ regularly \\
& $41.7 \%$ weekly & $17.1 \%$ weekly \\
& $30.6 \%$ seldom or never & $37.1 \%$ seldom or never \\
\hline Romania & $(\mathrm{n}=46)$ & $(\mathrm{n}=44)$ \\
& $8.7 \%$ regularly & $15.9 \%$ regularly \\
& $43.5 \%$ weekly & $18.2 \%$ weekly \\
& $47.8 \%$ seldom or never & $65.9 \%$ seldom or \\
& & Never \\
\hline Slovak Republic & $(\mathrm{n}=46)$ & $(\mathrm{n}=31)$ \\
& $0 \%$ regularly & $22.6 \%$ regularly \\
& $6.5 \%$ weekly & $19.4 \%$ weekly \\
& $93.5 \%$ seldom or never & $58.1 \%$ seldom or never
\end{tabular}

$x^{2}=11.994 \quad d f=2 \quad p=0.002$

Source: Own study.

Table 4. Frequency of young mothers' back pain

\begin{tabular}{lll}
\hline & 2011 Back pain & 2016 Back pain \\
& $\mathrm{N}=128$ & $\mathrm{~N}=110$ \\
\hline Hungary & $(\mathrm{n}=37)$ & $(\mathrm{n}=37)$ \\
& $41.7 \%$ never & $22.9 \%$ never \\
& $41.7 \%$ rarely & $42.9 \%$ rarely \\
& $16.7 \%$ frequently & $34.3 \%$ frequently \\
\hline Romania & $(\mathrm{n}=46)$ & $(\mathrm{n}=44)$ \\
& $32.6 \%$ never & $50 \%$ never \\
& $47.8 \%$ rarely & $36.4 \%$ rarely \\
& $19.6 \%$ frequently & $13.6 \%$ frequently \\
\hline Slovak Republic & $(\mathrm{n}=46)$ & $(\mathrm{n}=31)$ \\
& $4.3 \%$ never & $16.1 \%$ never \\
& $19.6 \%$ rarely & $48.4 \%$ rarely \\
& $76.1 \%$ frequently & $35.5 \%$ frequently \\
\hline
\end{tabular}

Source: Own study.

\section{Smoking habits}

We were able to notice a contradictory tendency between 2011 and 2016 in young mothers' smoking habits in all three nations jointly. The rate of young mothers who never smoke increased, but at the same time the proportion of daily smokers among them also increased a bit. Nevertheless, as a whole, significantly fewer young mothers smoke at present than five years ago $(\mathrm{p}=0.027)$ (Table 5).

Table 5. Changes in young mothers' smoking habits

\begin{tabular}{lll}
\hline & $\mathbf{2 0 1 1}(\mathrm{N}=128)$ & $\mathbf{2 0 1 6}(\mathrm{N}=110)$ \\
\hline Never & $75.8 \%$ & $85.5 \%$ \\
Seldom & $15.6 \%$ & $7.3 \%$ \\
Frequently & $3.9 \%$ & $0 \%$ \\
Daily & $4.7 \%$ & $7.3 \%$ \\
\hline
\end{tabular}

$\chi^{2}=9.167 \quad \mathrm{df}=3 \quad \mathrm{p}=0.027$

Source: Own study. 
We achieved remarkable results when we compared the smoking habits of young mothers according to their working status. There are significantly more smokers among working mothers than among housewives ( $\mathrm{p}=0.029$ ). With mothers working full time, the percentage of those who never smoke is $69.4 \%$, as opposed to $85.1 \%$ with unemployed mothers. The proportion of daily smokers among mothers working full time is three times higher than among unemployed mothers, while among young mothers working part time, the number of daily smokers is actually four times higher than the unemployed mothers (Table 6).

Table 6. Young mothers' smoking habits according to their working status $(\mathrm{N}=238)$

\begin{tabular}{llll}
\hline & $\begin{array}{l}\text { Full-time worker } \\
\mathrm{n}=93\end{array}$ & $\begin{array}{l}\text { Part-time worker } \\
\mathrm{n}=26\end{array}$ & $\begin{array}{l}\text { Unemployed } \\
\mathrm{n}=119\end{array}$ \\
\hline Never & $69.4 \%$ & $81.8 \%$ & $85.1 \%$ \\
Rarely & $16.1 \%$ & $3 \%$ & $11.3 \%$ \\
Frequently & $4.8 \%$ & $3 \%$ & $0.7 \%$ \\
Daily & $9.7 \%$ & $12.1 \%$ & $2.8 \%$ \\
\hline$\chi^{2}=14.059$ & $\mathrm{p}=0.029$ & &
\end{tabular}

$\chi^{2}=14.059 \quad \mathrm{df}=6 \quad \mathrm{p}=0.029$

Source: Own study.

There is no doubt that the basically positive tendency in the young mothers' smoking habits is due principally to the fact, that as members of the European Union, all three countries had to adapt some anti-smoking laws initiated by the European Commission (Romanian Parliament bans smoking, 2015; The Tobacco Atlas, 2017). Anti-smoking campaigns proved to be much more effective than anti-smoking campaigns.

\section{Conclusions}

It is always interesting to investigate the influence of important historical, social, and economic events and the special measures taken in connection with them in certain social groups. Although we were able to carry out an investigation among young mothers in only three countries in 2016, whereas we were able to study more countries in 2011, the results are still very instructive. The findings of our current research and how they compare to the relevant data of our previous investigation on the same subject shows that the recent world economic recession has had contradictory consequences on young mothers' social statuses and on their lifestyle choices and habits.

Nevertheless, the impact of the crisis did often appear only indirectly. The recession produced various challenges for the individual countries, and those countries answered these challenges in diverse ways depending on their political and economic preferences, cultural sensitivities, heritage, traditions, and customs. It is clear that the key changes occurred in the working statuses of the young mothers, and most other changes depended more or less on that factor.

However, for the most part, our research was only able to uncover the immediate causes of the changes in the young mothers' working statuses, their childcare solutions, and their frequency of physical activity, back pain, and smoking habits. The ultimate causes lying beneath the surface need still further exploration.

\section{REFERENCES}

Abonyi, B. (2013). Comparative study on physical activity and back pain of young mothers in some Eastern European countries. Physical Culture and Sport. Studies and Research, 60, 52-63.

Blaskó, Z. \& Gábos, A. (2013). Redistribution effects of the childcare system in Hungary. Who is cared for? Budapest: Budapest Institute. Retrieved May 30, 2017, from http://www.budapestinstitute.eu/uploads/V4_child_care_enrolment_HU1.pdf

European Commission. (2013). Project, Common Employment Report. Retrieved May 30, 2017, from http://ec.europa.eu/europe2020/pdf/2014/jer2014_hu.pdf

European Commission. (2016). National Social Report, Hungary. Retrieved May 31, 2017, from

ec.europa.eu/social/BlobServlet?docId=16102\&langId=hu 
European Commission. (2017). Public Health. Retrieved May 30, 2017, from http://ec.europa.eu/health/tobacco/smokefree_environments_en

Eurostat. (2015). Statistics of employment. Retrieved June 1, 2017, from http://ec.europa.eu/eurostat/statisticsexplained/index.php/Employment_statistics/hu

Eurostat. (2016). Self-perceived health statistics Retrieved May 31, 2017, from http://ec.europa.eu/eurostat/statisticsexplained/index.php/Self-perceived_health_statistics

Foldesi, Sz. G. (2014). The impact of the global economic crisis. Physical Culture and Sport. Studies and Research, 63, 22-30.

Gal, A. (2008). A magyar lakosság egészségtudatossága és szabadidő-sportolási szokásai [The Hungarian population’s health consciousness and its customs related to leisure sport]. In G.F. Foldesi, A. Gal, \& T. Dóczi (Eds.), Társadalmi riport a sportról [Social report on sport] (pp. 9-39). Budapest: Magyar Sporttudományi Társaság [Hungarian Society of Sport Science].

Global Finance Magazine. (2017a). Hungary GDP and Economic Data. Retrieved May 20, 2017, from http://www.gfmag.com/global-data/country-data/hungary-gdp-country-report

Global Finance Magazine. (2017b). Romania GDP and Economic Data. Retrieved May 20, 2017, from http://www.gfmag.com/global-data/country-data/romania-gdp-country-repor

Global Finance Magazine. (2017c). Slovak Republic GDP and Economic Data. Retrieved May 20, 2017, from https://www.gfmag.com/global-data/country-data/slovakia-gdp-country-report

Gyermekgondozási segély (GYES). (2016). Babaszoba [Baby’s room]. Retrieved May 21, 2017, from http://www.babaszoba.hu/articles/gyerek/Gyermekgondozasi_segely_GYES_2016?aid=20160111151319

Human Development Report, UNDP. (2010). The Real Wealth of Nations: Pathways to Human Development. Retrieved May 28, 2017, from http://hdr.undp.org/sites/default/files/reports/270/hdr_2010_en_complete_reprint.pdf

Human Development Report - Ranking, UNDP. (2015). Key to HDI Countries and Ranks, 2015. Retrieved May 28, 2017, from http://hdr.undp.org/sites/default/files/rankings.pdf

PERFAR (Population Europe Resource Finder \& Archive). (2014). Family Policies: Romania. Retrieved May 30, 2017, from http://www.perfar.eu/policy/family-children/romania

Romanian parliament bans smoking in bars and playgrounds. (2015, December 15). Reuters. Retrieved May 26, 2017, from http://www.reuters.com/article/us-romania-smoking-ban-idUSKBN0TY23T20151215

Ríos, D., Cubedo, M., \& Ríos, M. (2013). Graphical study of reasons for engagement in physical activity in European Union. Springer Plus. Retrieved May 25, 2017, from https://springerplus.springeropen.com/articles/10.1186/2193-1801$\underline{2-488}$

Special Eurobarometer 412 (2014). Sport and physical activity. Retrieved May 19, 2017, from http://ec.europa.eu/health/sites/health/files/nutrition_physical_activity/docs/ebs_412_en.pdf

The Tobacco Atlas. (2017). Slovakia. Retrieved May 26, 2017, from http://www.tobaccoatlas.org/country-data/slovakia/ Valkova, J. (2013). What is the direction of childcare policy in Visegrad countries? Budapest: Budapest Institute. Retrieved May 28, 2017, from http://budapestinstitute.eu/index.php/projektek/adatlap/the_evolution_of_day_care_provision_for_children_under_4/hu

$\begin{array}{ll}\text { AUTHOR'S ADDRESS: } & \text { Barbara Abonyi } \\ & \text { University of Physical Education } \\ & \text { Alkotás utca } 44 \\ & 1123 \text { Budapest, Hungary } \\ & \text { E-mail: abonyibarbara21@gmail.com }\end{array}$

Received: 28 January 2017; Accepted: 15 March 2017 